\title{
A CASE STUDY: SECOND LANGUAGE INVESTMENTS OF AN INTERNATIONAL STUDENT IN SHAPING IDENTITY
}

\author{
Devi Mulyani \\ Program of English Education, Faculty of Language and Art, University of Indraprasta PGRI \\ Jalan Nangka No. 58C Tanjung Barat, Jagakarsa, Jakarta Selatan 12530 \\ mulyadevi@yahoo.com
}

\begin{abstract}
The objective of this study is to find the ways of a postgraduate student in investing the language for shaping the second language identity in the local communities of practice in a city in the UK. This research is a case study which employs qualitative descriptive method. The data was gathered through diaries and interviews. Finding has shown that the subject of the research was active in the communities. The language investment was gained by involving actively in several communities in the UK. The finding also shows that there is no limitation to speak English from the native speakers in the communities. These finally shape the identity of the subject as a second language learner in the local communities. In conclusion, the investment in the local communities has shaped subject's second language identity.
\end{abstract}

Key words: second language learner, investment, identity

\begin{abstract}
ABSTRAK
Tujuan dari penelitian ini adalah untuk menemukan cara-cara seorang mahasiswa pascasarjana dalam melakukan investasi berbahasa untuk membentuk identitas bahasa kedua di komunitaskomunitas lokal sebagai praktik di sebuah kota di Inggris. Penelitian ini merupakan studi kasus yang menggunakan metode deskriptif kualitatif. Data dikumpulkan melalui buku harian dan wawancara. Hasil penelitian menunjukkan bahwa subjek penelitian aktif di komunitas tersebut. Investasi bahasa diperoleh dari keterlibatan subjek penelitian secara aktif di komunitas tersebut. Dengan demikian pada akhirnya subjek penelitian dapat membentuk identitas sebagai pembelajar bahasa kedua di masyarakat setempat. Kesimpulannya, investasi bahasa yang dilakukan oleh subjek penelitian di masyarakat setempat telah membentuk identitas bahasa keduanya.
\end{abstract}

Kata kunci: pembelajar bahasa kedua, investasi, identitas 


\section{INTRODUCTION}

Mitchell and Myles (2004:27) argue that "The second language learner as essentially a social being". They explain that second language learners in society involve in "structured social networks" and "social practices". Next, reading their concept of second language learner and society, it can be summarised that when second language learners involve in a community, they face the structure of society. In this situation there is a concept that closely related to learners selves. The concept of the learner and societies emerges identities and learning.

Second language can be learnt through formal and informal setting. Formal setting can be "classroom setting" and informal social contact, through work, through migration or other social forces that bring speakers of different languages into contact and make communication a necessity. It is known that in the classroom setting there is an instruction for the learners should follow. On the other side, second language learners can learn the language without instruction in informal setting; they can learn from environments that use the language naturally.

A situation which enables learners to learn without classroom instruction is illustrated in the following description. Second language learners come to a country which uses different language as theirs. This situation enables them to expose to a real world of second language situation. They enter a new community with a new language. This situation is more likely to encourage the learners to speak the target language. Settings that may persuade the learners to communicate can be in any places, for instance stores, supermarkets, housings, schools, clubs and parties. The illustration above is an example of "natural acquisition contexts" which is stated by Lightbown and Spada (2006:109).

As an English speaking country, it is known that the UK uses English as a tool to communicate. For those coming from outside the country, for example visitors from Asia should also employ the language to be conversed in the local society. The case also happens to the participant in this study. She came to the UK as a post-graduate student in a university in the country. She faced second language environment where local people and comers are neighbourhood and most of them use English in their interactions. In this situation she should deal with the decision of the way to invest her English in the communities. Therefore, the objective of this paper is to find the ways of a postgraduate student in investing in the shaping of her second language identity in the local communities of practice in a city in the UK. It is not aimed to find the weakness of the learner but to find the strength of her as Norton (1997:427) states that "The expansion of English in this era of rapid globalization may possibly be for the better rather than for the worse".

Reading Peirce (1995:17-18), it can be summarised that investment is not the same as 'instrumental motivation'. Norton (2000:10) explains that "The concept of motivation is drawn primarily from the field of social psychology, where attempts have been made to quantify of a learner's commitment to learning the target language". Peirce (1995:17-18) argues that investment as how world is changed by the second language learners as in this quotation, "The notion of investment, on the other hand, attempts to capture the relationship of the language learner to the changing social world. It conceives of the language learner as having a complex 
social identity and multiple desires". Next, she says in speaking with "The target language speaker", the learners regard themselves as "who they are" and "how they relate to the social world". It can be taken into account that second language learners are desire to change the world more likely deal with themselves and others. This idea can be explained that when the learners involve in their society they will show or find themselves. This is how they show themselves to their world and how they find themselves among society members.

One study about language identity and investment was conducted by Norton (2000). It is illustrated that Eva is an immigrant from Poland coming to Canada with two purposes; working and studying. She was aware that English is important to a better chance of getting jobs. For this she invested quite well in English. She used television and newspaper as tools to improve her English. Although she considered that English is very important to her career, she preferred to live with people who are from the same country. She chose it because of communication matter in term of understanding. Her opinion was that living with Polish had an ease to have understanding. She spoke Polish with her Polish friends. It is stated that she almost never spoke English with them.

Eva worked in a fast food restaurant. This should have been a place where she could practice English. She was the only worker who did not use English as first language. The other workers in the restaurant spoke English. As normally in a fast-food restaurant, they served customers to order food and drink in which they interacted in English. The interaction in English was limited to her, as prior to her current work in this restaurant she was a cleaning service worker. This did not give much access for her to practice English.

Working community was understood by Eva as a place to practice English. In contrast, she received disregard from members in the work. It impacted to interaction with people there. This resulted in the lack of her confidences especially in speaking. This situation is identified as an identity of second language learners that she had less chance to Speak English. She felt that she was exploited in her work society due to her English. Her efforts to improve English were not respected by the members. Once, she had opportunity to have other division in her job; cashier. This position, however, did not suffice her to improve her English because her manager created feeling anxiety to her. Difficulties she got in the workplace did not stop her to invest English. However, Norton explains more about change that Eva did in the workplace. Before, Eva preferred to remain quiet if there was underestimated statements. She had changed it by being courageous to reply directly if people treat her unfairly. This actions, Norton says, is her identity.

Here is an evaluation of Eva's case study. As a second language learner she was trying to invest language in her work. The struggles she faced here was from the environment itself. Naturally, in the world of work there is a hierarchy which places someone in a specific duty. In this case, she worked in the lowest level of position in this restaurant. Additionally, her language supported her partners to discriminate her in communication. It seems that her aim to have more possibility to speak English was not fully achieved. This is because her partners did not recognise her enthusiasm. If it is related to her identity, it can be weighed that her identity as an immigrant that had different language did not meet in this situation. Although it 
unpleasantly happened to her, her consistency to invest English through work community was still there. This can be concluded that the process of learning second language through naturalistic environment deals with the learner's identity toward society. In the work environment, language investment was committed by Eva as a second language leaner. Finally, Eva could prove that she was able to speak confidently with her co-workers.

\section{METHOD}

This research is a case study of a Chinese student, Jasmine, from a postgraduate programme of a University in the UK. Duff (2008:45) states that "A related advantage of case studies is that they can sometimes provide counterevidence to existing theoretical". Thomas (2009:115) states that "A case study involves in-depth research into one case or a small set of cases". Furthermore, Yin (2009:4) argues "The method is also relevant, the more that your questions require an extensive and "in-depth" description of some social phenomenon". Therefore, this research investigated evidence of the participant's investments in shaping her identity in the local communities in a city in the UK. The writer decided to involve her in this study because of her uniqueness. When she was studying and living in the UK, she preferred not to much involve in Chinese communities in there. However she liked to involve with local people in her community and other visitors of the UK at the time.

Jasmine decided to study in the UK because of the culture. She confirmed herself as a traditional lady and the UK provides politeness like in her country. She was born in China and has known English since she was in the primary school. She was 24 years old when this study was being conducted. She has agreed to participate in this research. She offered significant opportunity to the writer in order to gain information from her. This was the reason why she was chosen as the participant in this research. Her cooperation to have more investigation and interviews was also as other consideration she could entrust in this research.

Additionally, to protect the participant, pseudo-name is used in publication concerning privacy. There is also consent form signed by the participant and the researcher. To sum up, any ethical issues are very important resembling statement as "important responsibilities" Thomas (2009:147).

This paper uses qualitative framework which gains descriptive information. All information gathered was written and spoken data. The initial data was diaries used to initiate interview. First diary entry was at March 13 and second entry was at March 18, 2012. There are two sorts of information that were produced in the diaries; they were participant's background and her second language learning.

The first diary entry was participant's biography intended to make the writer understand the participant's background. Participant's biography was the entry point or starting point of this study. Moreover, this is supported by Norton (2000) that biographical insights are important in understanding the relationship between identity and language learning.

The second diary entry was about the participant's language interaction. In here participant was encouraged to write her experience in the UK. This was specifically her language experiences. It included data about to whom she communicated with, how she felt communicating with a person or people and what reason she interacted with 
them. The three sorts of data were aimed to have personal and social information related to her investment in language practice.

After having a diary data, interviews were carried out. These interviews were designed in order to get data that explained how she invested English in her communities in the UK. Finally, the interview result was viewed enough to gather related information.

Data analysis was started by transferring data of audio recorder to be data transcription. After that, data that stated the participant's investment were coded. After coding, data explanation or supporting data was identified. The data is about her perspective toward her English and how and why she is involved in the local communities. Her feeling in interaction during the activities in the communities was also important in analysis. People who interacted with her in these activities were also as explained.

\section{RESULTS AND DISCUSSION}

\section{Jasmine's Accommodation}

Jasmine wishes she had stayed with foreign flatmates. However most of Jasmine's flatmates were Chinese and one Taiwanese that made her disappointed and it was really not like she had expected. She said that there was no difference between living in her country and in the UK because they still spoke their language. She never spoke English with the flatmates because it was strange.

\section{Jasmine's Communication Problem}

At the first month of Jasmine's arrival to the UK she had some problems in communication. She were not really sure when she is ready to speak English in the community. She was afraid to speak with the local people there because of her personal matter and communication ability. She thought that her English must be extremely bad. Moreover she imaged herself that people might perceive her English was incredibly poor.

\section{Jasmine's Involvement in the Communities}

Although Jasmine found personal barrier in having contact at the first time of her arrival in the UK, she still committed to practice English. She was aware that coming to the UK was not only for studying but there was considerable chances to speak English with the local people and other visitors. As a result, Jasmine involved herself in several communities in the UK.

There were some ways that Jasmine did in society in the UK in order to deliberate herself to communicate with people. She was active to visit several groups in order to practice English and to know their culture. She met people in the church, local family, cafe, and English club.

Jasmine went to the church to meet people and talked with them. In the church she met British and international students. From the excerpt below, it can be explained how Jasmine thought about church related to her practice in English.

I think at first I really want communicate with people and the people in church are very friendly they liked to help me and talked with me everything ... I only wanted to communicate with people to practice my English.

Whether she thought that people in church could help her, she still faced problem in self-confidence. She did not have very good self-assurance when talking to people in the church at the first time. She said that she had problem in terms of feeling with the people. The problem was when she wanted to start communicating. This became more 
problematic because she did not have certain topic to talk.

Jasmine also had an effort to have relationship with local people in the UK. She visited local family in the UK. In the local family, she was invited to have dinner together with the other guesses. She said that the host was friendly to her. It is based her statement below.

It seems like I was in my room, I was in my all family. It seems like I am very familiar with them, not new friends, like very old friends. They are very nice.

However like in the church, Jasmine also worried to talk with the host at the first time. She had uneasiness regarding her English. She considered that her English was not good enough. She was not sure that living in UK for one month gave guarantee for her to have good communication with the local family.

The local people treated her very well when she visited their house at the first time. They encouraged her to have discussion with them by their attitudes and elicited any topics to her. This seemed to have feedback from her. She said that it made her like to talk with them.

After that, Jasmine still did not stop finding chances to practice English. She often went to a cafe. In this place, Jasmine spoke English more freely than in the church and the local people family. She said that she could speak anything in this place since they did not know each other. There was no doubt for her to worry about her privacy after talking with stranger. She felt that she can share any idea in there because it was a free discussion without intriguing individual life. Jasmine explained that meeting in the cafe was arranged to provide a certain topic for every week. Based on the topic she talked with others to answer some related questions to the topic.
She tried to make friends in the cafe with any people unless people from the same country as her. She explained enthusiastically that if she had a chance to speak with people from her country she tended to speak Chinese. The reason why she did is on her statement she said in the interview.

Sometimes do you know sometimes when you speak English with people in your own country you can easily can understand him and you don't have very big progress, because you have the same thinking pattern, you have the same accent, so it is very easily to understand each other. But I think if you talk with people from different country, you can make big progress and you can practice a lot. And I prefer to speak to local people.

Jasmine also came to an English club which was a small class with some volunteers from local people and an American Lady. They learnt pronunciation and proverb. They sat along the table and had the materials. Nevertheless, she did not visit to this club every week.

The main idea of communication based on Jasmine's opinion that using English as second language is a process. The important point she said that her progress in English is not about the number of English words she knows. What she pointed out is communication to people and understand what people communicated with.

\section{Comment}

In Jasmine's case, problem arises from herself as a second language learner. She created image of her English ability in the local communities. There was constrict communication with local people there. She was difficult to start speaking because of the picture of her 
poor English. However, it seems that Jasmines realised coming to the UK means practicing English as much as possible. Considering of herself did not have good English did not entirely stop investing English. She found herself as a brave person to speak out with people in the UK. This is proven by her investment in the local society. She attended several communities to practice English.

First she was interacting in the church where local people and international students were also coming. Church is seemed to facilitate her a very good opportunity to make communication comfortably. Since she declared herself as a person who was very emotional, the church likely gave chance to her for having such interactions gladly. Nevertheless, she seemed difficult to involve with people in the church at the first time. This is related to her ability in "pragmatic competence" which Hedge (2000:48) explains as "How to use language in order to achieve certain communicative goals or intentions".

When Jasmine was invited by British family, she still found difficulties in communication due to the poor English image. Jasmine created an opinion that her English is not qualified to speak with them. It is likely that she created a gap between her and the local people. She had not experienced to involve in a local family before. It likely impacted herself to be initiator in the conversation. She was quite hard to start communicating. Fortunately, the hosts were wise in understanding her. This made Jasmine liked to respond, talked and asked them many questions about living in the UK. This is a reality that as an English learner, Jasmine seems struggle in communicating in the naturalistic environment. The struggle is related to how she overcomes herself to encourage herself in conversation with people in this environment. She feels inferior in this situation.

Norton (2011:11) argues that "Interest in identity categories and language learning is gaining momentum". Thus, in this study, Jasmine found herself as a second language learner who is coming from China who did not like to always stick on with her friends from the same country. She was aware to be active in the communities in the exchange of having more prospects to speak English. Moreover, she had chances to speak English without restriction from the native speakers. This implies that she finds who herself in naturalistic environment. She knows how she should invest her English in the communities. This is an optimistic characteristic of Jasmine in constructing identity as Ortega's idea (2009:243) "That learners strive to construct positive identities for themselves". These finally shape Jasmine's identity as a second language learner in the local communities.

The process of Jasmine's investment in shaping identity is shown in the diagram below:
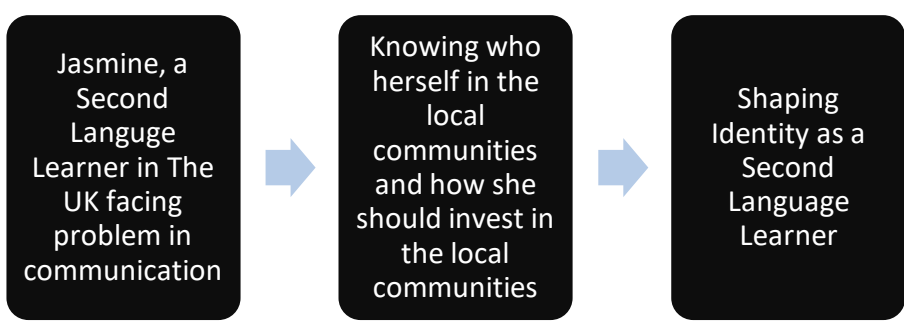


\section{CONCLUSION}

Naturalistic environment is a community where the second language learners can learn the target language directly. The UK as an English Speaking country is a kind of naturalistic environment. Second language learners of English usually meet here and integrate with the local people and other visitors.

Jasmine is a Chinese student who had visited the UK to study in a post graduate programme since September 2011. She had problems in communication with local people at the first time she just had come. She felt very afraid of her poor English. She was not very brave to speak in English at the first time. Although she found herself in bad situation of communication, she tried to involve in some social activities. She visited the church, the local family, the cafe, and the English study club. She did it in order to achieve her goal; speaking English.

Jasmine tended to not much involve in Chinese community in the UK in order to gain many opportunities to practice English. She found herself as a person who needed to engage in the local communities. As a Chinese, she believes that her community is important. However, she highly preferred to local people to practice English, and it was also possible for her to have communication in English with international students and other visitors. She has invested English in local communities although she was not too confident with her English. The other important issue is that she had a freedom to speak with the native speakers in the communities. This reflected her understanding about who herself and how she should invest in the local communities. In conclusion her investment in local community has shaped her identity.

In summary, it can be learned from Jasmine's case that a second language learner can find inferior feeling in English speaking country in term of language ability. It can make learner stays with people who have the same language. However, it did not happen to Jasmine. Communication problem could not stop her investing in the local communities. Next, it is recommended to study in how language investment of second language learner in a situation where has constriction from the local communities.

\section{REFERENCES}

Duff, P. A. (2008). Case Study Research in Applied Linguistics. New York: Lawrence Erlbaum Associates.

Hedge, T. (2000). Teaching and Learning in the Language Classroom. Oxford: Oxford University Press.

Lightbown, P. M., \& Spada, N. (2006). How Languages Are Learned, $3^{\text {nd }}$ (eds). Oxford: Oxford University Press.

Mitchell, R., \& Myles, F. (2004). Second Language Learning Theory, $2^{\text {nd }}$ $(E d s)$. Great Britain: Hodder Arnold.

Norton, B. (1997). Language, identity, and the ownership of English. TESOL Quarterly, 31(3), 409429.

(2000). Identity and Language Learning: Gender, Ethnicity, Educational Change. England: Pearson Education Limited.

(2011). Identity and Language Learning: Extending 
the Conversation, $2^{\text {nd }}$ (eds). Bristol: Multilingual Matters.

Ortega, L. (2009). Understanding Second Language Acquisition. Great Britain: Hodder Education.

Peirce, N. B. (1995). Social identity, investment, and language learning. TESOL Quarterly, 29(1), 9-31.
Thomas, G. (2009). How to Do Your Research Project: A Guide for Students in Education and Applied Social Sciences. London: SAGE.

Yin, R. K. (2009). Case Study Research: Design and Methods $\left(4^{\text {th }} e d\right)$. London: SAGE. 